\title{
The Distribution of Phosphorus Forms in Wuyi Rock Region and Its Effect on Tea Quality-Related Constituents in Tea Garden Soil
}

\author{
Hongmeng Ye ${ }^{1,2 *}$, Guoping $\mathrm{Li}^{1}$, Xuyin Yuan ${ }^{1,3}$, Huan $\mathrm{He}^{1,2}$, Hao Yang ${ }^{2 * *}$, Li Tang ${ }^{3}$ \\ ${ }^{1}$ Fujian Provincial Key Laboratory of Eco-Industrial Green Technology, College of Ecology and Resource Engineering, \\ Wuyi University, Wuyishan, 354300, China \\ ${ }^{2}$ School of Geography Science, Nanjing Normal University, Nanjing 210023, China \\ ${ }^{3}$ College of Environmental, Hohai University, Nanjing, 210098, China
}

Received: 15 November 2020

Accepted: 25 January 2021

\begin{abstract}
Phosphorus is an essential element for life, an innate constituent of soil organic matter, and a major anthropogenic input to terrestrial ecosystems. This paper employed the sequential extraction method for phosphorus fraction to study the distribution of phosphorus in different region in Wuyishan. Hierarchical cluster and correlation were used for investigating the relationship between the phosphorus form and tea quality-related constituents in Zhengyan Rock Tea (ZYRT), Banyan Rock Tea (BYRT) and Zhou Rock Tea (ZRT). The result showed that the concentration of phosphorus in different regions followed this order: ZYRT $>$ BYRT $>$ ZRT. The relative contribution of phosphorus fraction in different regions show the similar trend: Metal Oxide Bound Phosphorus $(\mathrm{NaOH}-\mathrm{P})>$ Calcium Bound Phosphorus (HCl-P) $>$ Reduced Phosphorus (BD-P) $>$ Adsorbed Phosphorus $\left(\mathrm{NH}_{4} \mathrm{Cl}-\mathrm{P}\right)$. The maximum content of water extract (WE), caffeine (CF), tea polyphenols (TPP) and total amount of amino acids (TAA) in tea leaves is in ZYRT, followed BYRT, and least in the ZRT. The phosphorus forms seem to have no obvious effects on the tea quality in the ZYRT and BYRT area, while TPP and NaOH-P, TPP and HCl-P are significantly positively correlated $(r=0.912, r=0.956, r=0.938 ; p<0.01)$ in ZRT.
\end{abstract}

Keywords: phosphorus forms, Wuyi Rock tea, Tea quality-related constituents, chemical extraction

\section{Introduction}

Tea is one of the most consumed nonalcoholic beverages, which possesses numerous benefits for human health, including anticancer, antioxidant

*e-mail: hongmengye@sina.com

properties, reduction of free radicals, and other unique health advantages [1-3]. As the birthplace of Chinese oolong and black teas, Wuyishan has a long history of tea production [4]. According to the different geographical environment, Wuyi Rock Tea has been classified as Zhengyan Rock Tea (ZYRT), Banyan Rock Tea (BYRT) and Zhou Rock Tea (ZRT). It is noted that the tea quality in Wuyishan is followed this order: ZYRT $>$ BYRT $>$ ZRT [5]. 
There are many factors contribute to tea quality, such as the characteristic of soil [6], the trace elements in the soil and phosphorus [7]. The functions of phosphorus cannot be neglected in the processes of photosynthesis and respiration of tea plant. Phosphorus in the soil plays an important role in the growth and yield of tea bush [8]. Phosphorus deficiency reduces the content of WE, TPP, TAA and theanine in green tea leaves, but increases the content of water-soluble sugar and phenolic ammonia ratio [9].

Studies have shown that TPP, TAA and WE of tea leaves have no significant relationship with the content of total phosphorus (TP) and organic phosphorus (OP) in soil $[10,11]$. However, it is not sufficient to draw conclusions about effect of the phosphorus on the tearelated constituents. Phosphorus exists in a variety of complex chemical forms, and not all the forms of phosphorus are likely to be released from particulates. Its morphologies and contents are affected by many factors, and may be subjected to variations in response to the evaluation of physical, chemical, and biological conditions. The form of phosphorus determines its migration, transformation, and bioavailability in the environment [12,13], and different forms of phosphorus might make different contributions to tea quality.

Phosphorus fraction's assessment can be made by determining the share of phosphorus in the mobile or immobile fraction [14]. Zhang et al. employed the chemical extraction to investigate the fate of fertilizer phosphorus in soil and phosphorus fractions with longterm phosphorus addition and depletion [15]. Previous studies [16] adopted the sequential extraction method for phosphorus fraction to study the distribution of phosphorus forms in riparian soils and peripheral river sediments. And result indicated that phosphorus, especially $\mathrm{NaOH}-\mathrm{P}$ and $\mathrm{HCl}-\mathrm{P}$, in riparian soil were mainly affected by agricultural activities. Therefore, it is a good choice for using the chemical extraction to analysis the correlation between phosphorus fraction in the tea garden soil and tea quality. However, few literatures reported the distribution of phosphorus fraction on the tea quality, especially in the Wuyi Rock tea.

Therefore, the objectives of this study are focusing on the distribution of phosphorus fraction in the tea garden soil of Wuyishan and the relationship between the phosphorus fraction and tea-quality constituents. Sequential extraction was conducted to determine the fractions of phosphorus. The samples (soil and tea leaves) are from 29 different sites (9 samples in ZYRT area, 11 samples in BYRT area and 9 samples in ZRT area) in Wuyishan. Clarifying the correlation between phosphorus forms and tea quality would help understand the characterization of phosphorus in Rock tea garden soil and provide a reference for the protection of ecological environment of the tea gardens, which ensures the utilization of phosphorus fertilizer.

\section{Material and Methods}

\section{Sample Collection}

The sample sites were conducted at Wuyishan, located in the Fujian province, China, at May 2017. The tea garden (spring tea) from tea gardens are harvested only once a year in April or May, and are further cultivated and weeded in the fall. Tea seed cakes and oil-tea cakes are often used to fertilize and control pests in most of the rock tea. The basic information of the tested samples from various rock tea gardens are present in Table 1. Rack tea garden could be separated into ZYRT, BYRT and ZRT. Shoots comprising four leaves and an apical bud was harvested. The soil in the

Table 1. Tea plantations characteristics.

\begin{tabular}{|c|c|c|c|c|c|c|c|c|c|}
\hline $\begin{array}{l}\text { Sample } \\
\text { No. }\end{array}$ & $\begin{array}{c}\text { Rock } \\
\text { area }\end{array}$ & Sample ID & Tea type & $\begin{array}{c}\text { Age } \\
\text { (years) }\end{array}$ & Soil type & $\begin{array}{l}\text { Longitude } \\
\text { (E) }\end{array}$ & $\begin{array}{l}\text { Latitude } \\
(\mathrm{N})\end{array}$ & $\begin{array}{l}\text { Altitude } \\
\text { (m) }\end{array}$ & $\begin{array}{l}\text { The amount } \\
\text { of fertilizer }\end{array}$ \\
\hline 1 & ZYRT & $\begin{array}{c}\text { Scenic Area } \\
\text { Center }\end{array}$ & Shuixian & 30 & $\begin{array}{l}\text { Moist sandy } \\
\text { soil }\end{array}$ & $117^{\circ} 55^{\prime} 58.96 "$ & $27^{\circ} 38^{\prime} 15.14^{\prime \prime}$ & 222 & $0.1 \mathrm{~kg} / \mathrm{m}^{2}$ \\
\hline 2 & ZYRT & $\begin{array}{c}\text { Scenic Area } \\
\text { Center }\end{array}$ & Shuixian & 30 & $\begin{array}{l}\text { Moist sandy } \\
\text { soil }\end{array}$ & $117^{\circ} 57^{\prime} 45.64$ " & $27^{\circ} 39^{\prime} 40.2 "$ & 346 & $\begin{array}{c}0.1 \mathrm{~kg} / \mathrm{m}^{2} \\
(\mathrm{OF})\end{array}$ \\
\hline 3 & ZYRT & $\begin{array}{c}\text { Scenic Area } \\
\text { Center }\end{array}$ & Shuixian & 30 & $\begin{array}{l}\text { Moist sandy } \\
\text { soil }\end{array}$ & $117^{\circ} 57^{\prime} 50.96 "$ & $27^{\circ} 39^{\prime} 54.64^{\prime \prime}$ & 349 & $0.15 \mathrm{~kg} / \mathrm{m}^{2}$ \\
\hline 4 & ZYRT & $\begin{array}{c}\text { Scenic Area } \\
\text { Center }\end{array}$ & Shuixian & 30 & $\begin{array}{l}\text { Moist sandy } \\
\text { soil }\end{array}$ & $117^{\circ} 57^{\prime} 37.9^{\prime \prime}$ & $27^{\circ} 39^{\prime} 56.42^{\prime \prime}$ & 338 & $\begin{array}{c}0.15 \mathrm{~kg} / \mathrm{m}^{2} \\
(\mathrm{OF})\end{array}$ \\
\hline 5 & ZYRT & $\begin{array}{c}\text { Scenic Area } \\
\text { Center }\end{array}$ & Shuixian & 30 & $\begin{array}{l}\text { Moist sandy } \\
\text { soil }\end{array}$ & $117^{\circ} 57^{\prime} 20.89^{\prime \prime}$ & $27^{\circ} 39^{\prime} 58.04^{\prime \prime}$ & 363 & $0.2 \mathrm{~kg} / \mathrm{m}^{2}$ \\
\hline 6 & ZYRT & $\begin{array}{c}\text { Scenic Area } \\
\text { Center }\end{array}$ & Shuixian & 30 & $\begin{array}{l}\text { Moist sandy } \\
\text { soil }\end{array}$ & $117^{\circ} 57^{\prime} 50.83^{\prime \prime}$ & $27^{\circ} 38^{\prime} 23.56^{\prime \prime}$ & 228 & $\begin{array}{l}0.2 \mathrm{~kg} / \mathrm{m}^{2} \\
(\mathrm{OF})\end{array}$ \\
\hline 7 & ZYRT & $\begin{array}{c}\text { Scenic Area } \\
\text { Center }\end{array}$ & Shuixian & 30 & $\begin{array}{l}\text { Moist sandy } \\
\text { soil }\end{array}$ & $117^{\circ} 57^{\prime} 24.79^{\prime \prime}$ & $27^{\circ} 38^{\prime} 32.44^{\prime \prime}$ & 248 & $\begin{array}{c}0.2 \mathrm{~kg} / \mathrm{m}^{2} \\
(\mathrm{OF})\end{array}$ \\
\hline 8 & ZYRT & $\begin{array}{c}\text { Scenic Area } \\
\text { Center }\end{array}$ & Shuixian & 30 & $\begin{array}{l}\text { Moist sandy } \\
\text { soil }\end{array}$ & $117^{\circ} 58^{\prime} 2.14^{\prime \prime}$ & $27^{\circ} 38^{\prime} 30.41^{\prime \prime}$ & 218 & $\begin{array}{l}0.2 \mathrm{~kg} / \mathrm{m}^{2} \\
(\mathrm{OF})\end{array}$ \\
\hline
\end{tabular}


Table 1. Continued.

\begin{tabular}{|c|c|c|c|c|c|c|c|c|c|}
\hline 9 & ZYRT & $\begin{array}{c}\text { Scenic Area } \\
\text { Center }\end{array}$ & Shuixian & 30 & $\begin{array}{l}\text { Moist sandy } \\
\text { soil }\end{array}$ & $117^{\circ} 57^{\prime} 44.75^{\prime \prime}$ & $27^{\circ} 38^{\prime} 24.63 ”$ & 226 & $\begin{array}{c}0.2 \mathrm{~kg} / \mathrm{m}^{2} \\
(\mathrm{OF})\end{array}$ \\
\hline 10 & BYRT & $\begin{array}{c}\text { Xing } \\
\text { Village }\end{array}$ & Shuixian & 30 & Purple soil & $117^{\circ} 59^{\prime} 56^{\prime \prime}$ & $27^{\circ} 44^{\prime} 18^{\prime \prime}$ & 219 & $0.1 \mathrm{~kg} / \mathrm{m}^{2}$ \\
\hline 11 & BYRT & $\begin{array}{c}\text { Xing } \\
\text { Village }\end{array}$ & Shuixian & 30 & Purple soil & $117^{\circ} 59^{\prime} 57^{\prime \prime}$ & $27^{\circ} 44^{\prime} 20^{\prime \prime}$ & 227 & $0.1 \mathrm{~kg} / \mathrm{m}^{2}$ \\
\hline 12 & BYRT & $\begin{array}{c}\text { Xing } \\
\text { Village }\end{array}$ & Shuixian & 30 & Purple soil & $117^{\circ} 59^{\prime} 41^{\prime \prime}$ & $27^{\circ} 36^{\prime} 34^{\prime \prime}$ & 258 & $0.1 \mathrm{~kg} / \mathrm{m}^{2}$ \\
\hline 13 & BYRT & $\begin{array}{c}\text { Xing } \\
\text { Village }\end{array}$ & Shuixian & 30 & Purple soil & $117^{\circ} 59^{\prime} 42^{\prime \prime}$ & $27^{\circ} 36^{\prime} 33^{\prime \prime}$ & 258 & $0.1 \mathrm{~kg} / \mathrm{m}^{2}$ \\
\hline 14 & BYRT & $\begin{array}{c}\text { Xing } \\
\text { Village }\end{array}$ & Shuixian & 30 & Purple soil & $117^{\circ} 56^{\prime} 52.30^{\prime \prime}$ & $27^{\circ} 48^{\prime} 34.68^{\prime \prime}$ & 258 & $0.15 \mathrm{~kg} / \mathrm{m}^{2}$ \\
\hline 15 & BYRT & $\begin{array}{c}\text { Xing } \\
\text { Village }\end{array}$ & Shuixian & 30 & Purple soil & $117^{\circ} 54^{\prime} 21.57^{\prime \prime}$ & $27^{\circ} 37^{\prime} 58.65^{\prime \prime}$ & 246 & $\begin{array}{c}0.1 \mathrm{~kg} / \mathrm{m}^{2} \\
(\mathrm{OF})\end{array}$ \\
\hline 16 & BYRT & $\begin{array}{c}\text { Xing } \\
\text { Village }\end{array}$ & Shuixian & 30 & Purple soil & $117^{\circ} 54^{\prime} 24.14^{\prime \prime}$ & $27^{\circ} 37^{\prime} 58.95^{\prime \prime}$ & 257 & $\begin{array}{c}0.15 \mathrm{~kg} / \mathrm{m}^{2} \\
(\mathrm{OF})\end{array}$ \\
\hline 17 & BYRT & $\begin{array}{c}\text { Xing } \\
\text { Village }\end{array}$ & Shuixian & 30 & Purple soil & $117^{\circ} 55^{\prime} 57.87^{\prime \prime}$ & $27^{\circ} 36^{\prime} 59.61 "$ & 298 & $\begin{array}{c}0.2 \mathrm{~kg} / \mathrm{m}^{2} \\
(\mathrm{OF})\end{array}$ \\
\hline 18 & BYRT & $\begin{array}{c}\text { Xing } \\
\text { Village }\end{array}$ & Shuixian & 30 & Purple soil & $117^{\circ} 55^{\prime} 57.87^{\prime \prime}$ & $27^{\circ} 36^{\prime} 59.61^{\prime \prime}$ & 298 & $0.15 \mathrm{~kg} / \mathrm{m}^{2}$ \\
\hline 19 & BYRT & $\begin{array}{c}\text { Xing } \\
\text { Village }\end{array}$ & Shuixian & 30 & Purple soil & $117^{\circ} 55^{\prime} 56.89^{\prime \prime}$ & $27^{\circ} 36^{\prime} 55.43^{\prime \prime}$ & 322 & $0.2 \mathrm{~kg} / \mathrm{m}^{2}$ \\
\hline 20 & BYRT & $\begin{array}{c}\text { Xing } \\
\text { Village }\end{array}$ & Shuixian & 30 & Purple soil & $117^{\circ} 19^{\prime} 57^{\prime \prime}$ & $27^{\circ} 36^{\prime} 04^{\prime \prime}$ & 194 & $\begin{array}{c}0.2 \mathrm{~kg} / \mathrm{m}^{2} \\
(\mathrm{OF})\end{array}$ \\
\hline 21 & ZRT & Wufu & Shuixian & 30 & $\begin{array}{l}\text { Yellowish } \\
\text { red soil }\end{array}$ & $118^{\circ} 20^{\prime} 87^{\prime \prime}$ & $36^{\circ} 02^{\prime} 79^{\prime \prime}$ & 193 & $\begin{array}{c}0.2 \mathrm{~kg} / \mathrm{m}^{2} \\
(\mathrm{OF})\end{array}$ \\
\hline 22 & ZRT & Wufu & Shuixian & 30 & $\begin{array}{l}\text { Yellowish } \\
\text { red soil }\end{array}$ & $118^{\circ} 18^{\prime} 54^{\prime \prime}$ & $27^{\circ} 36^{\prime} 7.08^{\prime \prime}$ & 202 & $0.2 \mathrm{~kg} / \mathrm{m}^{2}$ \\
\hline 23 & ZRT & Wufu & Shuixian & 30 & $\begin{array}{l}\text { Yellowish } \\
\text { red soil }\end{array}$ & $118^{\circ} 17^{\prime} 61^{\prime \prime}$ & $36^{\circ} 06^{\prime} 56^{\prime \prime}$ & 235 & $\begin{array}{c}0.2 \mathrm{~kg} / \mathrm{m}^{2} \\
(\mathrm{OF})\end{array}$ \\
\hline 24 & ZRT & Wufu & Shuixian & 30 & $\begin{array}{l}\text { Yellowish } \\
\text { red soil }\end{array}$ & $118^{\circ} 20^{\prime} 43^{\prime \prime}$ & $36^{\circ} 04^{\prime} 03^{\prime \prime}$ & 188 & $\begin{array}{c}0.15 \mathrm{~kg} / \mathrm{m}^{2} \\
(\mathrm{OF})\end{array}$ \\
\hline 25 & ZRT & Wufu & Shuixian & 30 & $\begin{array}{l}\text { Yellowish } \\
\text { red soil }\end{array}$ & $118^{\circ} 9^{\prime} 50^{\prime \prime}$ & $27^{\circ} 36^{\prime} 28^{\prime \prime}$ & 450 & $\begin{array}{c}0.2 \mathrm{~kg} / \mathrm{m}^{2} \\
(\mathrm{OF})\end{array}$ \\
\hline 26 & ZRT & Wufu & Shuixian & 30 & $\begin{array}{l}\text { Yellowish } \\
\text { red soil }\end{array}$ & $118^{\circ} 9^{\prime} 41^{\prime \prime}$ & $27^{\circ} 36^{\prime} 34^{\prime \prime}$ & 400 & $0.1 \mathrm{~kg} / \mathrm{m}^{2}$ \\
\hline 27 & ZRT & Wufu & Shuixian & 30 & $\begin{array}{l}\text { Yellowish } \\
\text { red soil }\end{array}$ & $118^{\circ} 9^{\prime} 42^{\prime \prime}$ & $27^{\circ} 36^{\prime} 33^{\prime \prime}$ & 420 & $\begin{array}{c}0.1 \mathrm{~kg} / \mathrm{m}^{2} \\
(\mathrm{OF})\end{array}$ \\
\hline 28 & ZRT & Wufu & Shuixian & 30 & $\begin{array}{l}\text { Yellowish } \\
\text { red soil }\end{array}$ & $117^{\circ} 56^{\prime} 52.30^{\prime \prime}$ & $27^{\circ} 48^{\prime} 34.68^{\prime \prime}$ & 325 & $0.2 \mathrm{~kg} / \mathrm{m}^{2}$ \\
\hline 29 & ZRT & Wufu & Shuixian & 30 & $\begin{array}{l}\text { Yellowish } \\
\text { red soil }\end{array}$ & $117^{\circ} 56^{\prime} 46.86^{\prime \prime}$ & $27^{\circ} 48^{\prime} 29.62 ”$ & 328 & $0.15 \mathrm{~kg} / \mathrm{m}^{2}$ \\
\hline
\end{tabular}

Note: Organic Fertilizer (OF)

study area are characterized as Nitisols with a friable clay texture and derived from 0 to $100 \mathrm{~mm}$ top layer.

\section{Sample Processing}

The soil samples were first cleaned of gravel, plant roots, dead branches, and other impurities to perform the element fraction analysis. Subsequently, the soil samples were milled, dried in natural atmosphere, and further purified by a 20 -mesh sieve $(0.841 \mathrm{~mm})$. Finally, the samples were mixed uniformly and quartered. For each measurement, $200 \mathrm{~g}$ of the soil samples were taken out, ground in an agate grinder, passed through a 100 -mesh sieve $(0.147 \mathrm{~mm})$, and properly stored.

The tea leaves samples in fresh condition were rinsed repeatedly with tap water to remove adhesive dust and debris, and further rinsed two or three times with deionized water. The clean leaves were then 
dried in air at room temperature, followed by another drying at $60^{\circ} \mathrm{C}$ until constant weight. Subsequently, the dried leaves were crushed and filtered by an 80 -mesh (0.177 mm).

\section{Methods}

\section{Tea Quality Measurement}

The collected tea leaves samples were subjected to the following biochemical analyses according ISO test methods to check their compliance to the ISO requirements (Table 2).

The ratio of tea polyphenols and amino acids (RAS) of the sample was calculated with the following equation:

$$
\mathrm{RAS}=\frac{\mathrm{m}_{0}}{\mathrm{~m}_{1}}
$$

Note: $\mathrm{m}_{0}$ and $\mathrm{m}_{1}$ is the amount of TPP and TAA, respectively.

Coefficient of variation (CV) of the sample was calculated with the following equation:

$$
\mathrm{CV}=\frac{\mathrm{SD}}{\mathrm{MN}} * 100 \%
$$

...were the SD and MN is stand for the standard deviation and average of sample.

\section{Determination of Soil Chemical Properties}

Soil samples are analyzed with total nitrogen (TN) measured using the concentrated $\mathrm{H}_{2} \mathrm{SO}_{4}$ digestion method and total phosphorus (TP) determined by the molybdate colorimetric method with perchloric acid digestion. $\mathrm{pH}$ was measured with a glass electrode in a slurry of $10 \mathrm{~g}$ of soil and $25 \mathrm{~cm}^{3}$ of deionized water. The organic matter $(\mathrm{OM})$ in the sediments is measured after treatment with $\mathrm{K}_{2} \mathrm{Cr}_{2} \mathrm{O}_{7} / \mathrm{H}_{2} \mathrm{SO}_{4}$ according to the Walkley-Black method.

TP in sediments can be divided as inorganic phosphorus (IP) and organic phosphorus (OP). IP can be divided as weakly adsorbed phosphorus $\left(\mathrm{NH}_{4} \mathrm{Cl}-\mathrm{P}\right)$, reduced phosphorus (BD-P), metal oxide bound phosphorus (NaOH-P) and calcium bound phosphorus (HCl-P). Among them, $\mathrm{NH}_{4} \mathrm{Cl}-\mathrm{P}, \mathrm{BD}-\mathrm{P}$ and $\mathrm{NaOH}-\mathrm{P}$ are

Table 2. ISO recommended chemical parameters for tea.

\begin{tabular}{|c|c|c|}
\hline Parameter & Test method & Reference \\
\hline Water extract (\%) (WE) & ISO 9768 & {$[17]$} \\
\hline Tea polyphenols (\%) (TPP) & ISO 14502-1 & {$[18]$} \\
\hline Caffeine (\%) (CF) & ISO 4052 & {$[19]$} \\
\hline $\begin{array}{c}\text { The total amount of amino acids } \\
(\%)(T A A)\end{array}$ & $\begin{array}{c}\text { Ninhydrin } \\
\text { method }\end{array}$ & {$[20]$} \\
\hline
\end{tabular}

the bioavailable forms of phosphorus (BAP $=\mathrm{NH}_{4} \mathrm{Cl}-\mathrm{P}$ + BD-P + NaOH-P = IP - HCl-P), while HCl-P mainly comes from clastic rocks and autogenous sources [21]. Indeed, HCl-P is the most stable form and can be regarded as a permanent sink of phosphorus. In other words, IP is difficult to be utilized by organisms. The extraction processes of phosphorus are shown in Fig. 1. Each phosphorus fraction was quantitatively assessed by the molybdenum blue/ascorbic acid method, and more details of extraction can be found in the references. The experiments were repeated for three times and the relative deviations of the results were kept below $5 \%$.

\section{Data Analysis}

In this study, hierarchical cluster and correlation were used for factors selecting. Hierarchical cluster analysis (HCA), an unsupervised learning process, divides similar objects into group or more subsets through static classification, and members in the same subset have similar properties, which use Euclidean distances [22] to calculate the distance (similarity) between different categories of data points. A more general alternative is the weighted Euclidean distance between two vectors $\mathrm{x}_{\mathrm{i}}$ and $\mathrm{x}_{\mathrm{j}}$

$$
\mathrm{d}_{\mathrm{i}, \mathrm{j}}=\left[\sum_{\mathrm{k}=1}^{\mathrm{K}} \mathrm{w}_{\mathrm{k}}\left(\mathrm{x}_{\mathrm{i}, \mathrm{k}}-\mathrm{x}_{\mathrm{j}, \mathrm{k}}\right)^{2}\right]^{1 / 2}
$$

For $\mathrm{w}_{\mathrm{k}}=1$ for $\mathrm{k}-1, \ldots, \mathrm{K}$, Equation (2-3) reduces to the ordinary Euclidean distance.

Correlation analysis refers to the analysis of two or more related variable elements to measure the closeness of the two variables factors [23]. The Person correlation coefficient, the covariance of the two variables divided by the product of their standard deviations, was used to measure the degree of correlation in this study. Correlation analysis and one-way ANOVA were performed using SPSS (version 22.0 for windows) and the figure in this paper was compiled by Origin 9.0 and Seaborn in Python 3.7.

\section{Results and Discussion}

\section{The Distribution of Elements in the Rock Tea Garden Soil}

The elements in tea garden soil are shown in Fig. 2, $\mathrm{Si}, \mathrm{Al}$, and $\mathrm{Fe}$ are the main elements in the soil [24]. The element of Si in the ZYRT area was highest with $51.56 \%$, and in the ZRT area soil was lowest with $39.84 \%$. Compared with BYRT and ZRT, the amount of $\mathrm{Al}$ and $\mathrm{Fe}$ in ZYRT area was lowest, with $9.91 \%$ and $2.60 \%$, respectively. The present of $\mathrm{Al}$ and $\mathrm{Fe}$ would have the effect on the phosphorus in the NaOH-P [25]. In these three different areas, the element of $\mathrm{Ca}$ and $\mathrm{Mn}$ also have some discrepancy. The proportion of $\mathrm{Ca}$ in 


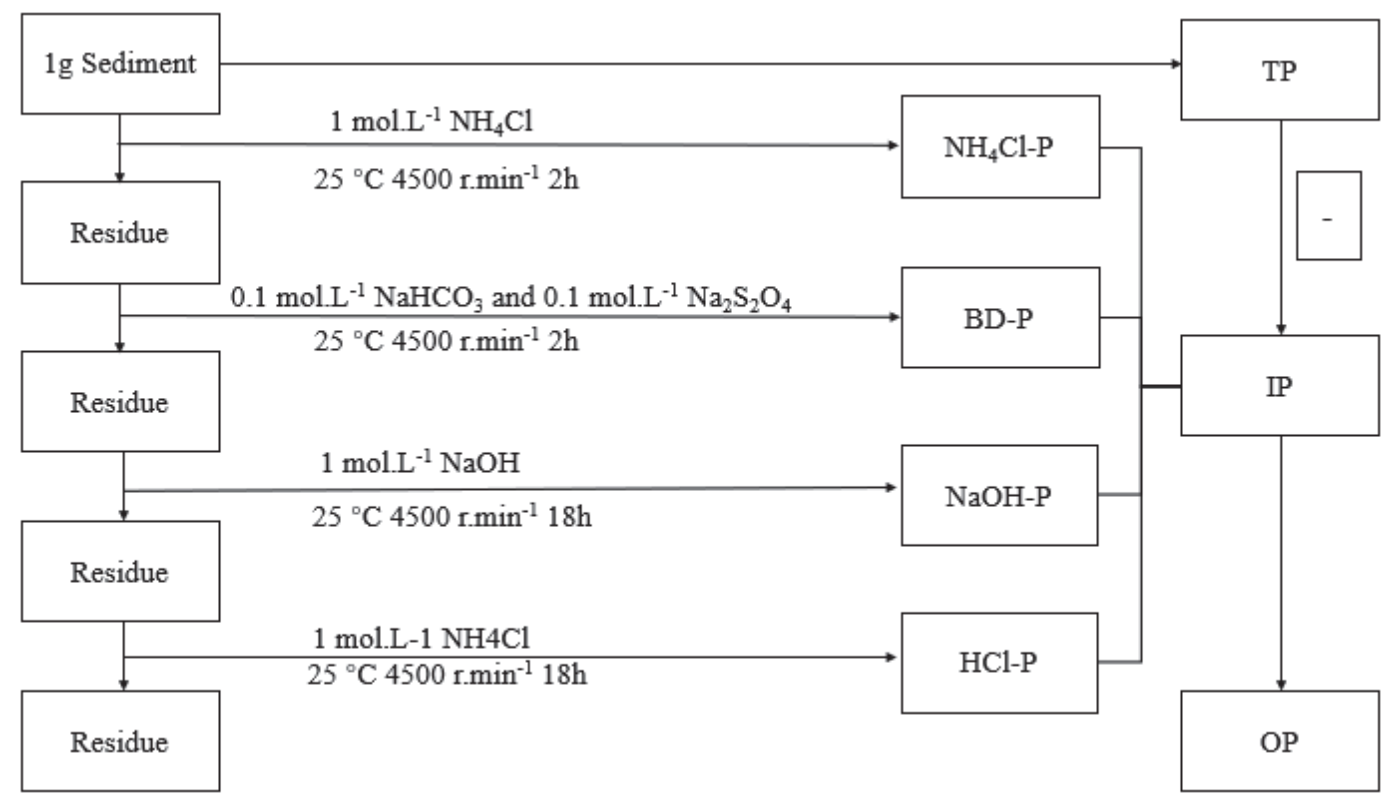

Fig. 1. The extraction processes of phosphorus in sample.

ZRT area is lower than other place, and the percentage of $\mathrm{Mn}$ in this place is $0.12 \%$. Some researchers [26] suggested that the form of phosphorus like HCl-P may be subjected to the element of $\mathrm{Ca}$ and $\mathrm{Mn}$.

\section{Chemical Characteristics of the Rock Tea Garden Soil}

Fig. 3 shows the chemical characteristics of the rock tea garden soil in different regions. The range of $\mathrm{pH}$ value in ZYRT, BYRT, and ZRT soil area were 4.32, 4.51, and 4.59, respectively, as the Fig. 3 shown. Literatures [27] have shown that $\mathrm{pH}$ optima of tea growth condition were between 4.2 and 5.5, which indicate that the soil of Wuyi Rock area is suitable for tea growth.

The value of OM, TN, TP, AN and AP followed the order: ZYRT>BYRT>ZRT. The OM content in the ZYRT, BYRT and ZRT were 31.52, 29.55, and $28.85 \mathrm{mg} / \mathrm{kg}$, respectively. It indicated that Wuyishan has a fertile soil and its fertility meets the standard of first-class soil fertility in the regulation of Technical Condition of a Tea-Producing Area (NY/T 853-2004) [28].

Compared with BYRT and ZRT, the content of TN in ZYRT is 1626 and $1407 \mathrm{mg} / \mathrm{kg}$, respectively, in Fig. 3. Meanwhile, the scale of AN in ZYRT and BYRT are approximately equal (110 and $101 \mathrm{mg} / \mathrm{kg}$ ). By contrast, the main AN distribution in ZRT was $80 \mathrm{mg} / \mathrm{kg}$. as the available nitrogen is also vital factor for the tea bush growth, the discrepancy of AN in ZRT, BYRT and ZRT maybe result in the tea quality [29]. Fig. 3 plots that both the amount of TP and AP in ZYRT are higher than in other area, which may contribute to the reason that the tea quality in ZRT better than other places [30].
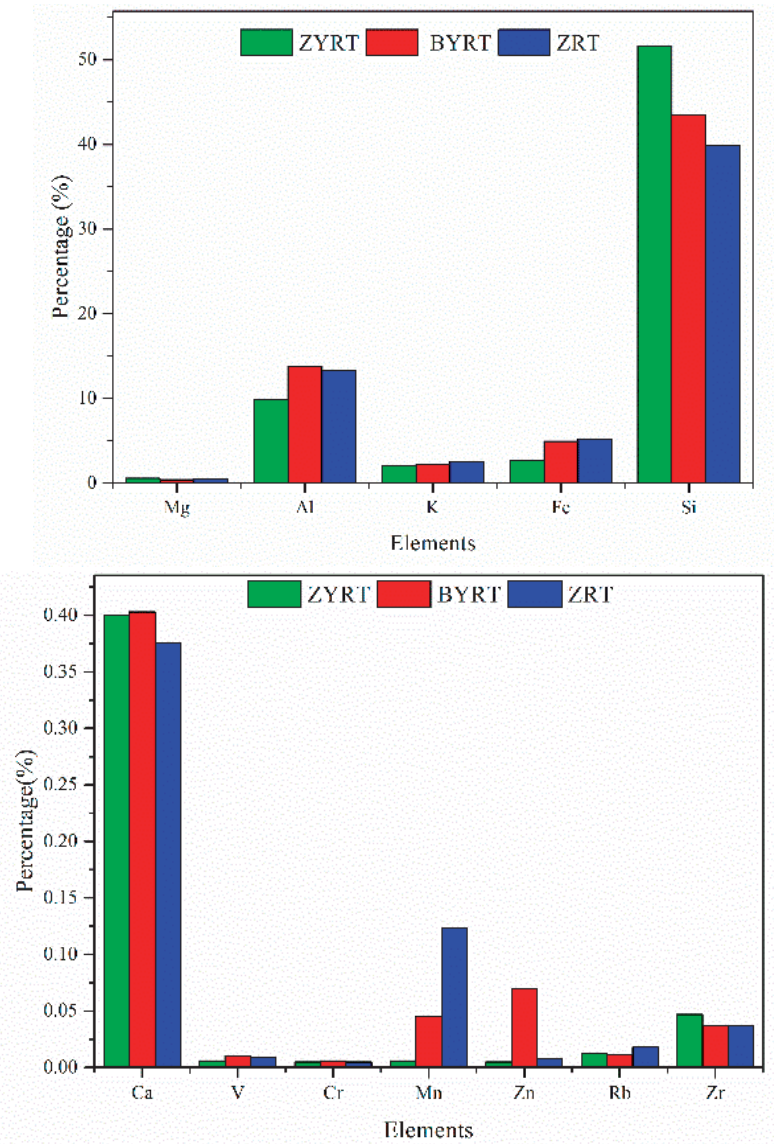

Fig. 2. Comparison of the elements in the tea soil garden tea in different regions. 

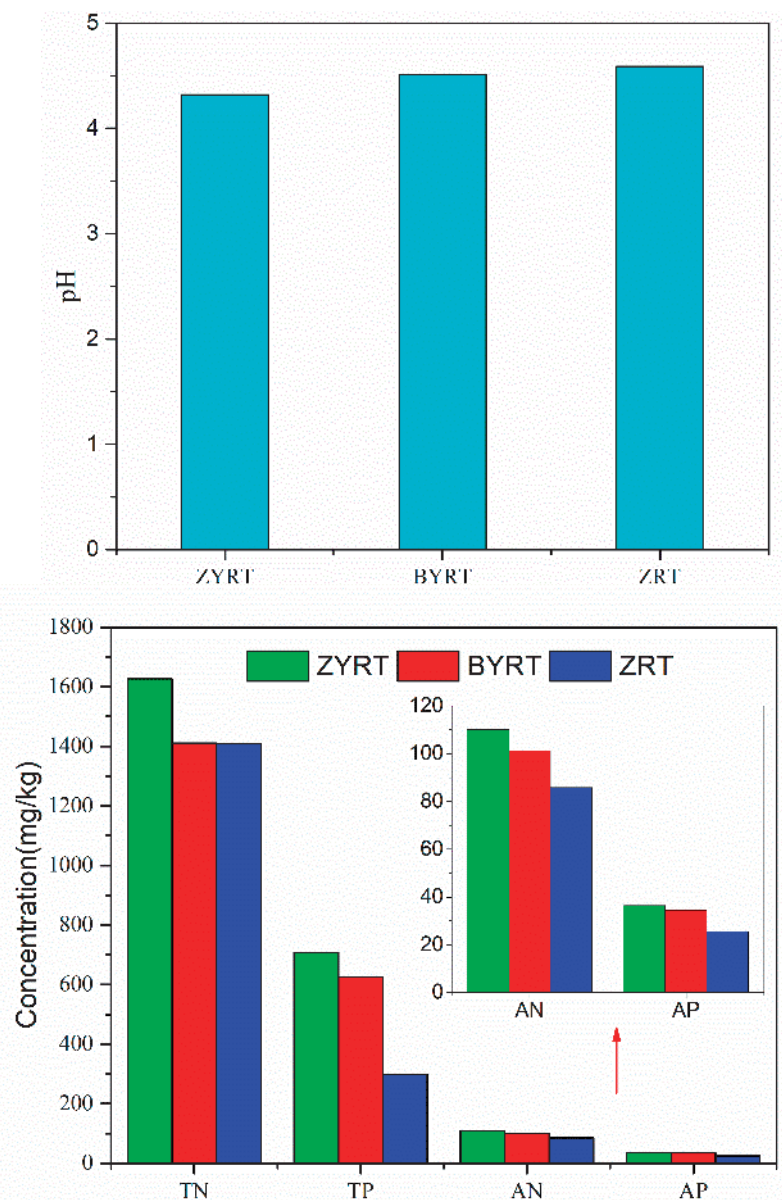

Fig. 3. Distribution of nutrient elements in tea garden soil.

\section{Effect of the Different Type of Soils on the Form of Phosphorus}

In order to further study the characteristics of phosphorus fractions, the proportion of phosphorus fraction contents and relative contribution values
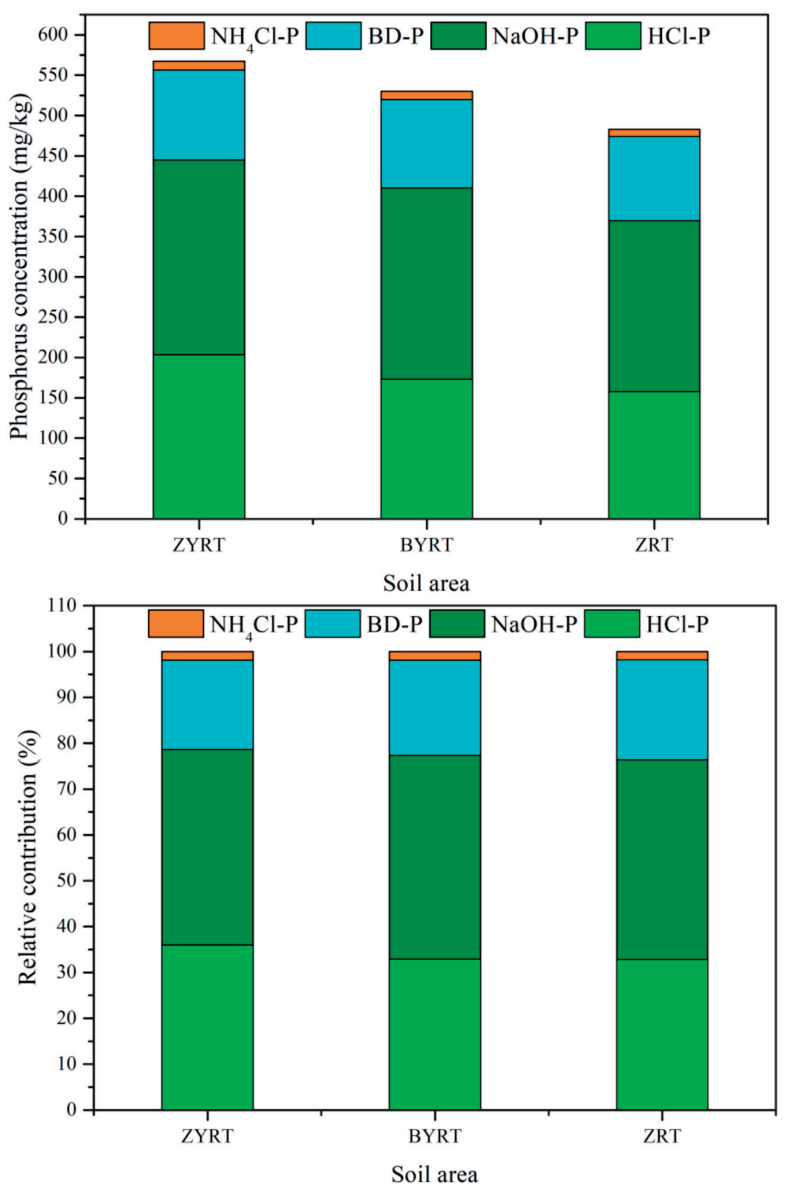

Fig. 5. Average of concentrations and proportions of phosphorus fraction in different regions.

associated with different phosphorus forms in different regions was plotted in Fig. 4. In ZYRT, the concentration of phosphorus increased with the amount of applying fertilizers. Inputting $0.1 \mathrm{~kg} / \mathrm{m}^{2}, 0.15 \mathrm{~kg} / \mathrm{m}^{2}$, and $0.2 \mathrm{~kg} / \mathrm{m}^{2}$ compound fertilizer in the $1^{\text {st }}, 3^{\text {rd }}$, and $5^{\text {th }}$
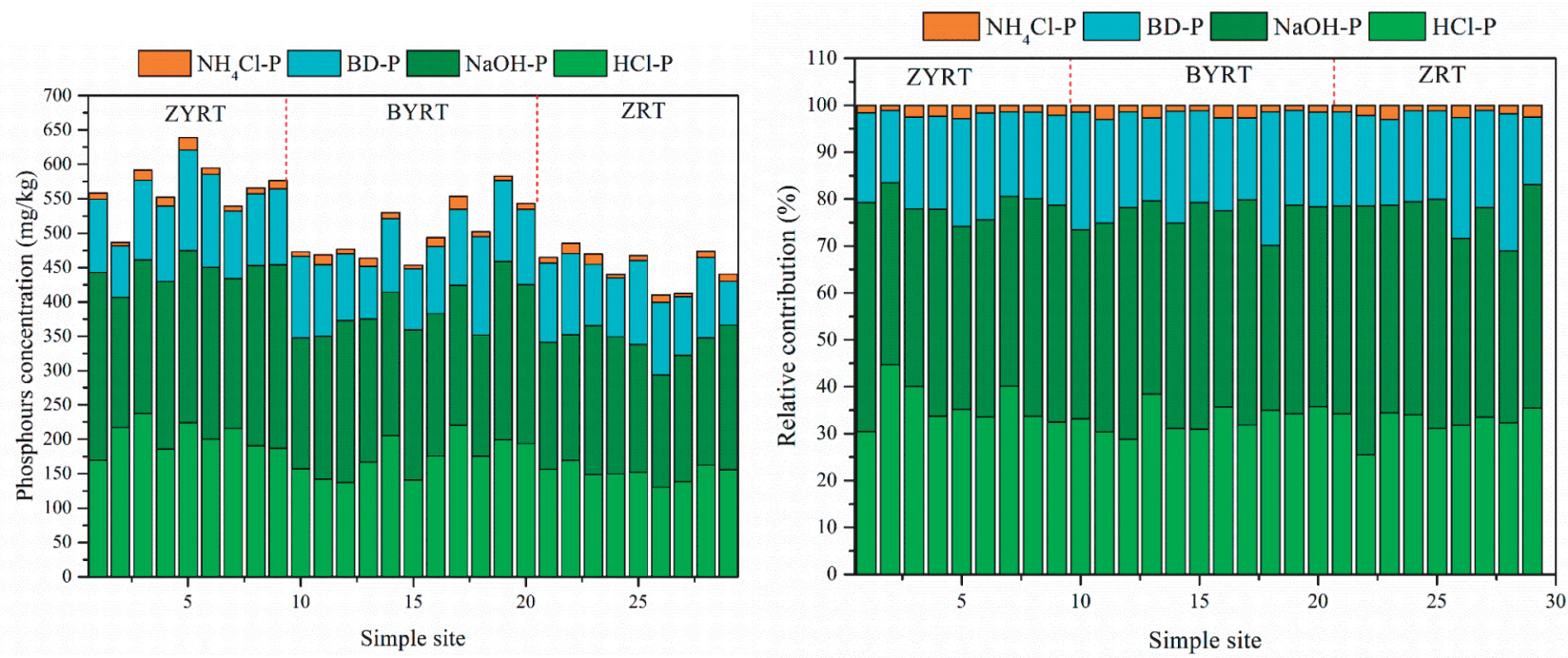

Fig. 4. Concentrations and proportions of phosphorus fraction in different regions. 
sample site, respectively, and phosphorus concentration follow this order: $5^{\text {th }}(639.248 \mathrm{mg} / \mathrm{kg})>3^{\text {rd }}(591.66 \mathrm{mg} / \mathrm{kg})$ $>1^{\text {st }}(558.44 \mathrm{mg} / \mathrm{kg})$. Meanwhile, the $2^{\text {nd }}\left(0.1 \mathrm{~kg} / \mathrm{m}^{2}\right.$ organic fertilizer $), 4^{\text {th }}\left(0.15 \mathrm{~kg} / \mathrm{m}^{2}\right.$ organic fertilizer $)$ and $6^{\text {th }}\left(0.2 \mathrm{~kg} / \mathrm{m}^{2}\right.$ organic fertilizer $)$ sample sites also show the similar trends.

As for BYRT tea garden soil, the first and second largest amount of phosphorus in the soil at the $19^{\text {th }}$ and $17^{\text {th }}$ with $582.84 \mathrm{mg} / \mathrm{kg}$ and $553.55 \mathrm{mg} / \mathrm{kg}$. The data of phosphorus at the $10^{\text {th }}, 11^{\text {th }}, 12^{\text {th }}, 13^{\text {th }}$ and $16^{\text {th }}$ sample sites were not obvious different. Related to ZRT garden soil, phosphorus concentration is almost at the same level except the $26^{\text {th }}$ and $27^{\text {th }}$. These two simple sites were applied compound fertilizer $\left(0.1 \mathrm{~kg} / \mathrm{m}^{2}\right)$ and organic fertilizer $\left(0.1 \mathrm{~kg} / \mathrm{m}^{2}\right)$, respectively.

The distribution of phosphorus forms at all sample sites except $2^{\text {nd }}$ and $7^{\text {th }}$ in ZYRT tea garden mainly follow this pattern: $\mathrm{NaOH}-\mathrm{P}>\mathrm{HCl}-\mathrm{P}>\mathrm{BD}-\mathrm{P}>\mathrm{NH}_{4} \mathrm{Cl}-\mathrm{P}$. While the distribution of phosphorus fraction at $2^{\text {nd }}$ and $7^{\text {th }}$ sample sites follows this order: $\mathrm{HCl}-\mathrm{P}>\mathrm{NaOH}-\mathrm{P}>\mathrm{BD}-$ $\mathrm{P}>\mathrm{NH}_{4} \mathrm{Cl}-\mathrm{P}$. By contrast, the ranking of four phosphorus forms in BYRT and ZRT follow an unchanged pattern, $\mathrm{NaOH}-\mathrm{P}>\mathrm{HCl}-\mathrm{P}>\mathrm{BD}-\mathrm{P}>\mathrm{NH}_{4} \mathrm{Cl}-\mathrm{P}$ at all sampling point. And phosphorus fraction in the BYRT and ZRT main in the $\mathrm{NaOH}-\mathrm{P}$ and $\mathrm{HCl}-\mathrm{P}$ form, with total percentage of its in NaOH-P and HCl-P to IP more than $70 \%$.

Fig. 5 plotted the average of concentrations and proportion of phosphorus fraction in different regions. The concentration of phosphorus in different regions followed this order: ZYRT $>$ BYRT $>$ ZRT, which is in agreement with others researchers' conclusions [31]. While the relative contribution of phosphorus fraction in different regions show the similar trend: $\mathrm{NaOH}-\mathrm{P}>\mathrm{HCl}-$ $\mathrm{P}>\mathrm{BD}-\mathrm{P}>\mathrm{NH}_{4} \mathrm{Cl}-\mathrm{P}$, which indicated that the phosphorus

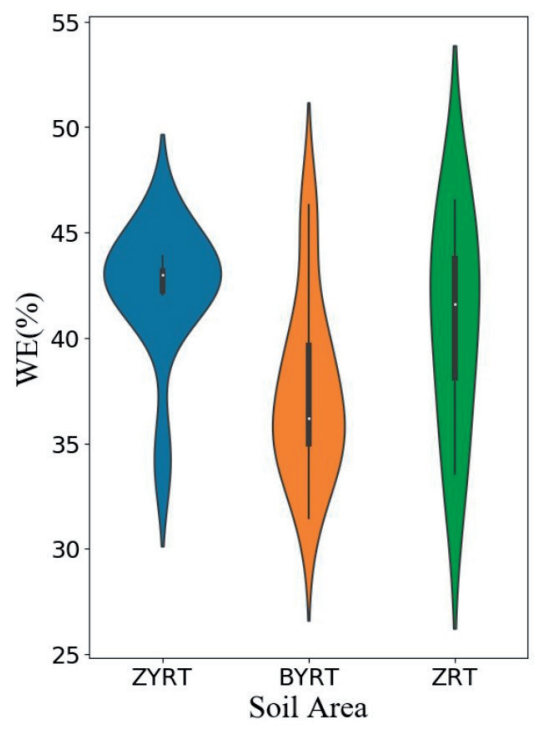

a) WE

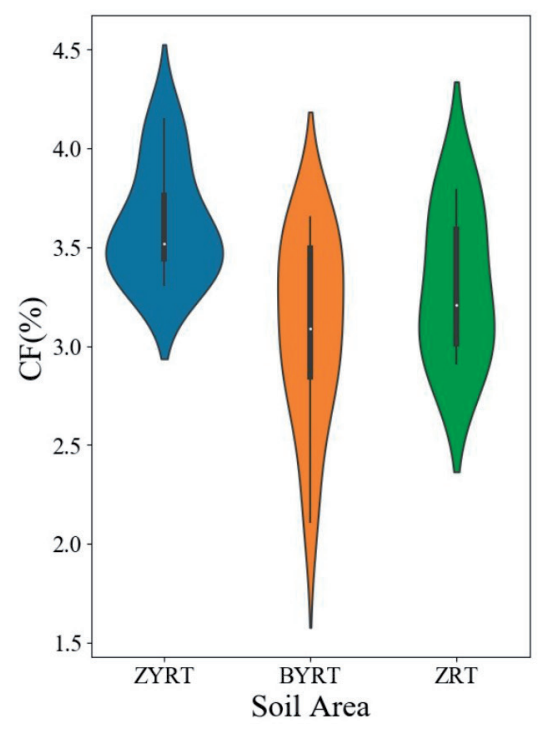

b) $\mathrm{CF}$

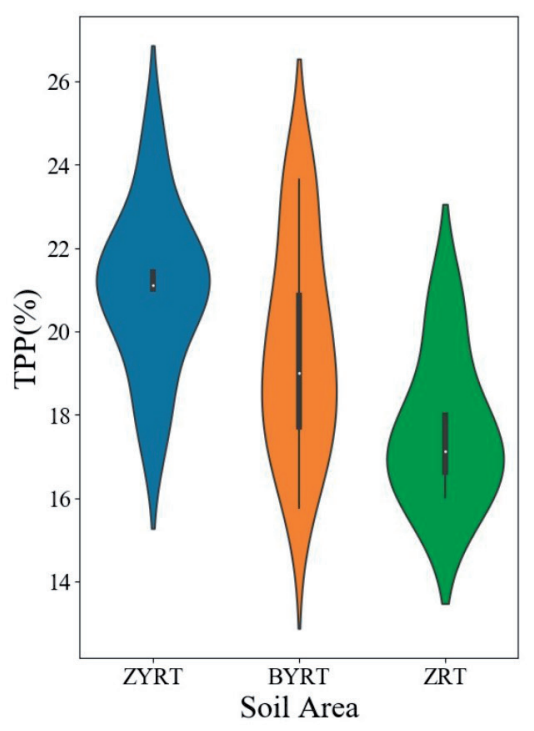

c) TPP

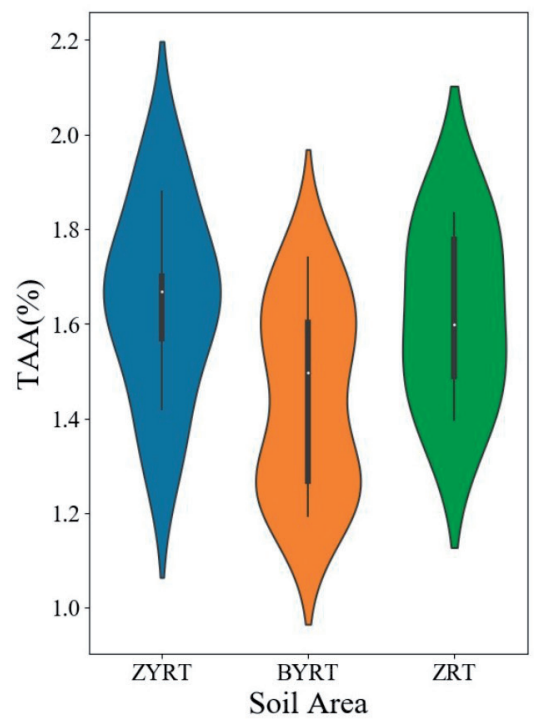

d) TAA

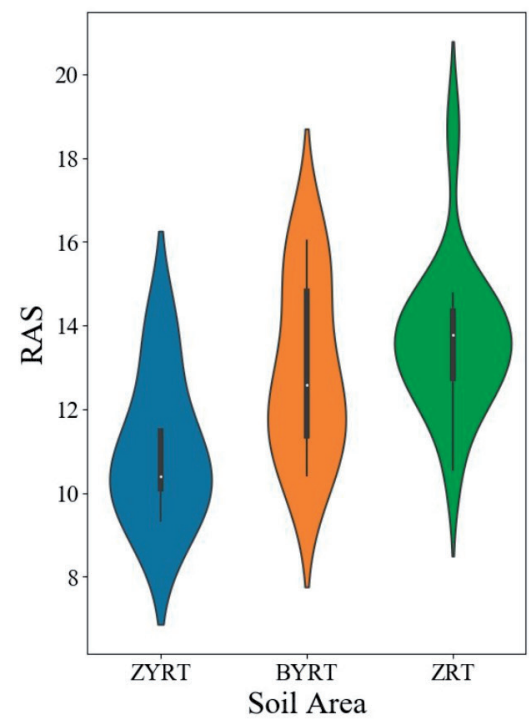

e) RAS

Fig. 6. the distribution of tea quality-related constituents. 
forms in the different regions show the same trends in Wuyi rock tea.

\section{The Characteristics of Tea Quality}

The violin plot features a kernel density estimation of the underlying distribution. Fig. 6 plots the distribution of tea quality-related constituents (WE, CF, TPP, TAA and RAS) in ZYRT, BYRT and ZRT garden area. WE, CF, TPP, TAA and RAS are crucial indexes to evaluate the tea quality [32].

As plotted in the Fig. 6a), the possibility of WE from the ZYRT leaves was $40 \sim 45 \%$, while the content of WE in BYRT area was lower than that in ZYRT, with $30 \sim 40 \%$. Compared with the leaves from ZYRT and BYRT area, the amount of WE in tea bush from the ZRT ranged from $27 \%$ to $53 \%$. This phenomenon indicated that the content of WE in tea leaves was fluctuated, which may lead to the tea quality from this area is unstable.

The distribution of CF from tea leaves seems more concentrated than that in another place, the $\mathrm{CV}$ of $\mathrm{CF}$ in ZYRT, BYRT and ZRT was in $6.58 \%, 14.33 \%$ and $10.21 \%$, respectively (Fig. $6 \mathrm{~b}$ ). TPP in tea leaves have the ability to reduce the risk of a variety of diseases and it also cannot be neglected parameter for tea quality [33]. The probability of TPP content in ZYRT and ZRT show the "spindle" shape, but the value of TPP in ZYRT area is higher than that in ZRT area. As for
BYRT soil area, the scale of TPP values cover the range from $13 \%$ to $27 \%$.

Amino acid mainly represents the N-Compounds in tea quality-related constituents and the main material makes the tea soup fresh and fragrant [34]. Fig. 6d) indicated that the percentage of TAA in tea leaves from ZYRT, BYRT and ZRT area was 1.1 2.2\%, 0.8 1.8\%, and $1.1 \sim 2.1 \%$, respectively. Many researchers [35] suggested that it is not reasonable to use the amino acid to evaluate the tea quality, because the type of amino acid is various and different.

Therefore, it seems that using the RAS is more available than only Amino index. The average of RAS in ZYRT, BYRT and ZRT was 11.02, 12.94 and 13.69, respectively. The fresh and brisk taste increases as the ratio of RAS decreases. In other word, the higher the ratio of RAS, the poorer the fresh and brisk taste.

\section{HCA and Correlation Analysis}

\section{$H C A$}

A heat map (Fig.7) was created using seaborn (version 1.0) to visualize the content composition in different regions: red, purple and cyan areas indicate high, low, and moderate levels of chemical composition, respectively. Hierarchical cluster analysis, an unsupervised learning process, divides similar objects
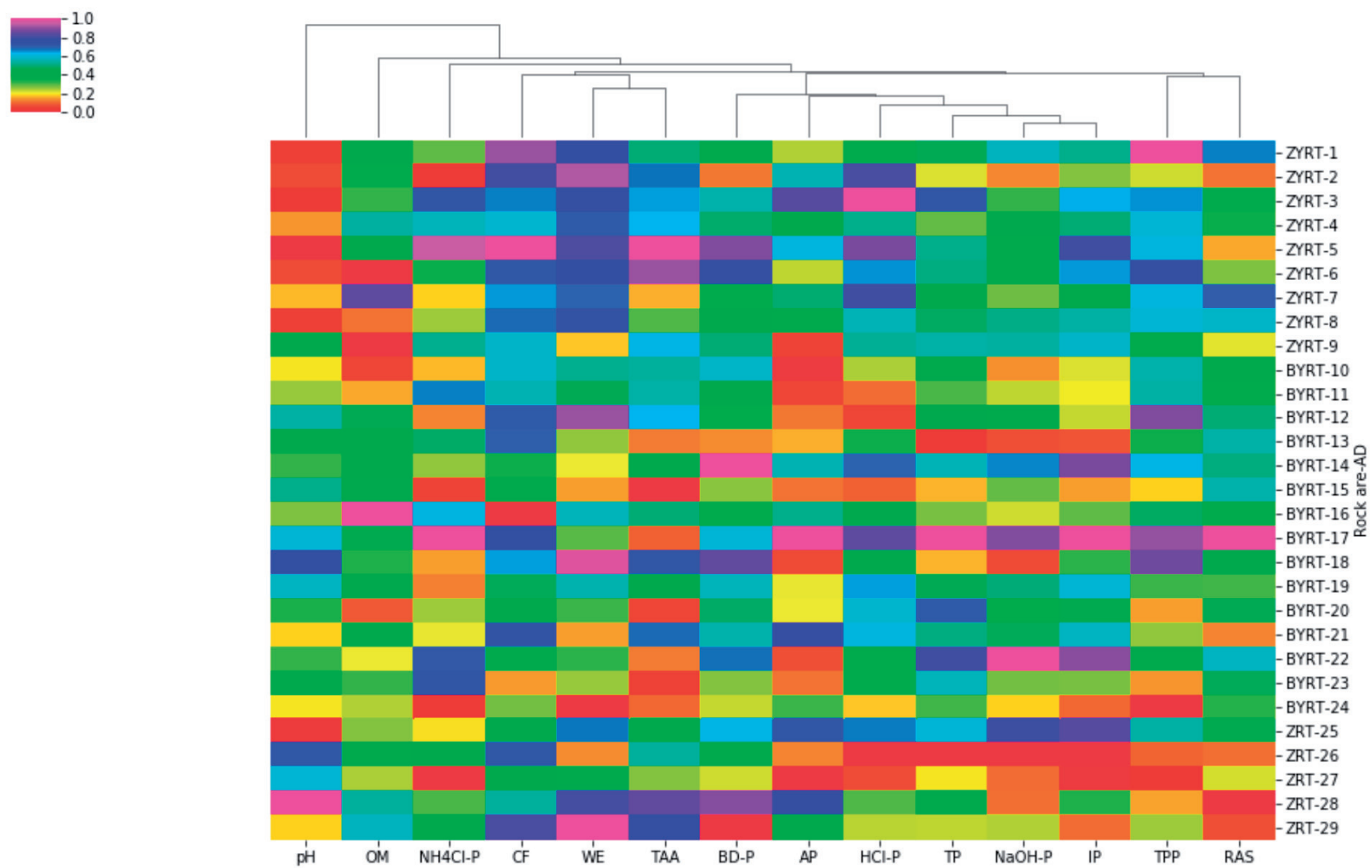

Fig. 7. Heat map of 14 variables and the results of hierarchical clustering for origins. 
into groups or more subsets through static classification, and members in the same subset have similar properties, which use Euclidean distance to calculate the distance (similarity) between different categories of data points. 14 variables could be divided into four categories: I (IP, NaOH-P, TP, HCl-P, AP, BD-P), II (TPP and RAS),

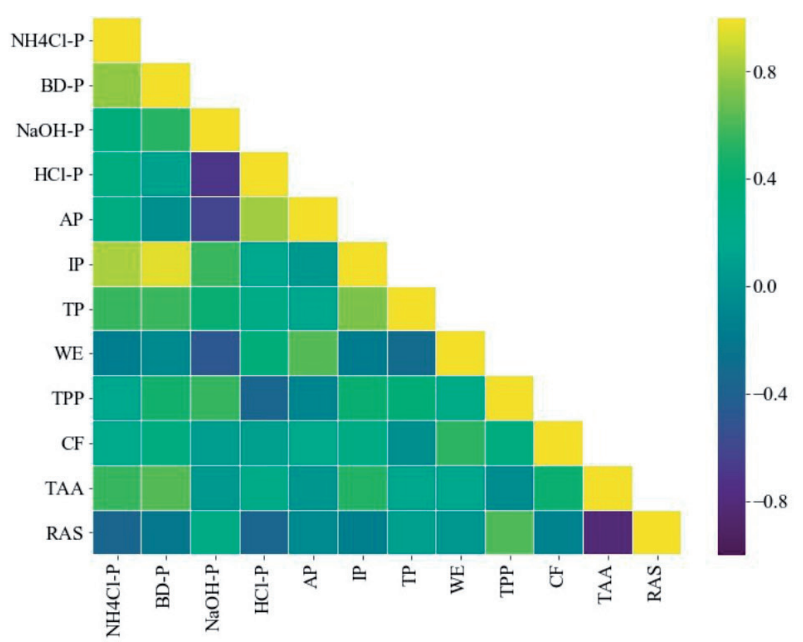

a) ZYRT

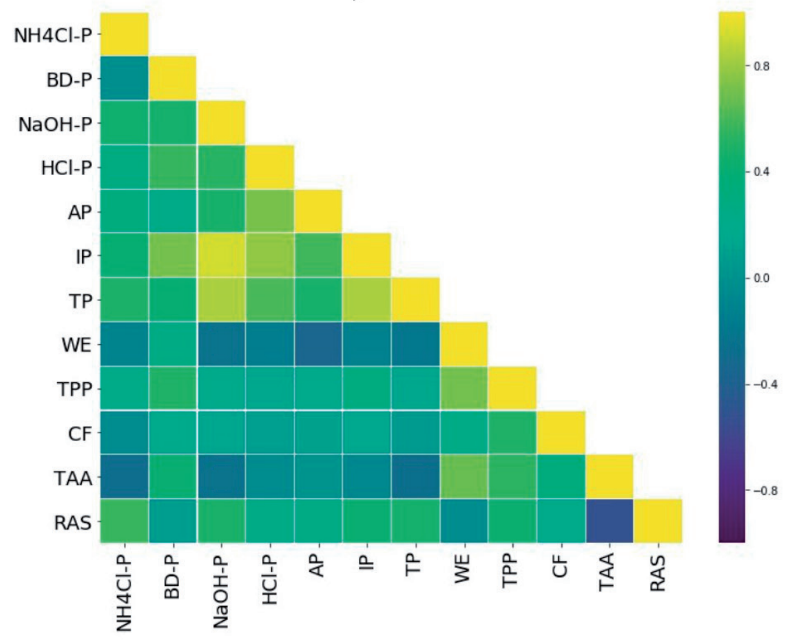

b) BYRT

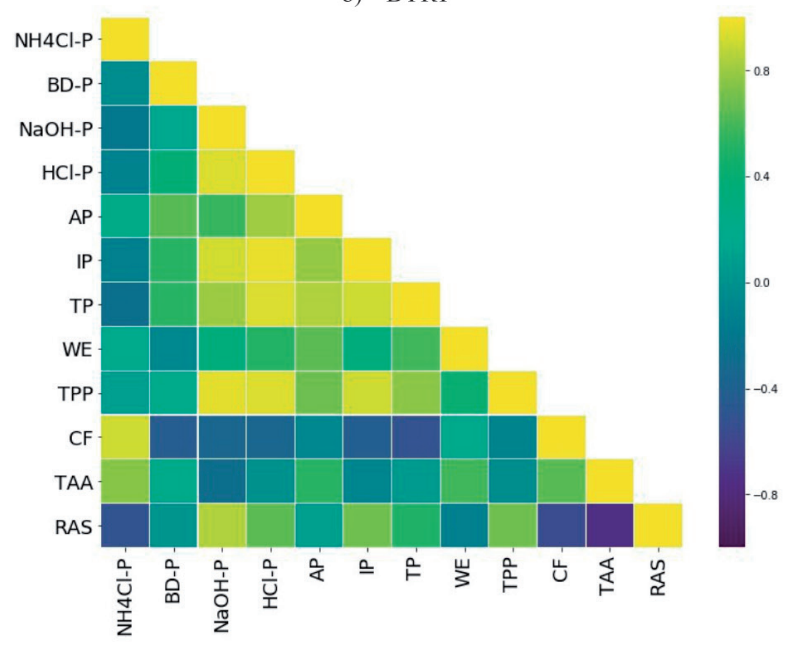

c) ZRT

Fig. 8. Person's correlation coefficients of $\mathrm{p}$ distribution and tea quality in different regions: a) ZYRT; b) BYRT; c) ZRT.
III (TAA, WE and CF), and other $\left(\mathrm{NH}_{4} \mathrm{Cl}-\mathrm{P}, \mathrm{OM}\right.$, and $\mathrm{pH})$. The distance from I to II and III is approximately equal, which indicate that the phosphorus fraction except $\mathrm{NH}_{4} \mathrm{Cl}-\mathrm{P}$ have significant correlation with tea indexes.

\section{Correlation Analysis}

The Pearson correlation coefficient matrix of phosphorus forms in different regions is shown in Fig. 7a), which shows that the $\mathrm{NH}_{4} \mathrm{Cl}-\mathrm{P}$ with $\mathrm{BD}-\mathrm{P}$ and IP contents in ZYRT areas are significantly positively correlated $(\mathrm{r}=0.774, \mathrm{p}<0.01 ; \mathrm{r}=0.84, \mathrm{p}<0.05)$. And the correlation coefficient between BD-P contents and IP contents value reached $0.959(\mathrm{p}<0.05)$. while the relationship between $\mathrm{NaOH}-\mathrm{P}$ contents and $\mathrm{HCl}-\mathrm{P}$ is negative $(r=-0.691, p<0.01)$. It seems that the phosphorus form may have some relationship with tea quality-related indexes. there are some indexes indicated the negatively correlated in ZYRT garden soil: WE content and $\mathrm{NH}_{4} \mathrm{Cl}-\mathrm{P}(\mathrm{r}=-0.163)$, WS contents and BD-P $(\mathrm{r}=-0.065)$, WS contents and $\mathrm{NaOH}-\mathrm{P}$ $(r=-0.483)$, and TAA contents and HCl-P $(r=-0.345)$. On the contrary, the rest of tea quality constituents and phosphorus fraction seem positive relationship, especially between TPP content and NaOH-P content $(\mathrm{r}=0.454)$, TAA and BD-P content $(\mathrm{r}=0.558)$.

As for BYRT area, phosphorus fraction shows the similar correlation in WE and TAA: BD-P have positive correlation with WE $(r=0.259)$ and TAA $(r=0.408)$, while the relationship with the rest of phosphorus fraction ( $\mathrm{NH}_{4} \mathrm{Cl}-\mathrm{P}, \mathrm{NaOH}-\mathrm{P}$, and $\left.\mathrm{HCl}-\mathrm{P}\right), \mathrm{WE}$ and TAA show a negative trend.

In the ZRT garden area, TPP and $\mathrm{NaOH}-\mathrm{P}$, TPP and HCl-P are significantly positively correlated $(\mathrm{r}=0.912$, $\mathrm{r}=0.956, \mathrm{r}=0.938 ; \mathrm{p}<0.01)$, suggesting that the tea quality like CF and TPP are subjected by HCl-P and $\mathrm{NaOH}-\mathrm{P}$. While other phosphorus fraction has negative correlation with $\mathrm{CF}$, the correlation value of $\mathrm{CF}$ and BD-P, NaOH-P, and HCl-P is $-0.43,-0.348$, and -0.344 , respectively.

In conclusion, it seems that the tea quality indexes and phosphorus forms only in ZRT area have high correction, and it is not obvious in ZYRT and BYRT rock area.

\section{Conclusions}

We have investigated the distribution of phosphorus fraction in different tea garden soil and the effect of phosphorus form on the tea quality in Wuyishan. The result indicated that the content of OM, TN, TP, AN and AP in different regions in Wuyishan followed this order: ZYRT $>$ BYRT $>$ ZRT. The concentration of phosphorus in different regions also followed same order. In addition, the relative contribution of phosphorus fraction in different regions show the similar trend: 
$\mathrm{NaOH}-\mathrm{P}>\mathrm{HCl}-\mathrm{P}>\mathrm{BD}-\mathrm{P}>\mathrm{NH}_{4} \mathrm{Cl}-\mathrm{P}$. The content of WE, CF, TPP and TAA in tea leaves is largest in ZYRT, followed BYRT, and last in the ZRT. The phosphorus forms seem have not obviously effects on the tea quality in the ZYRT and BYRT area, while TPP and $\mathrm{NaOH}-\mathrm{P}$, TPP and HCl-P are significantly positively correlated $(r=0.912, r=0.956, r=0.938 ; p<0.01)$ in ZRT.

\section{Acknowledgements}

This research was supported by General Program of China Postdoctoral Science Foundation (2019M661874), Natural Science Foundation of Fujian Province (2020J05218), and Research and Start-up Project of Talent Introduction of Wuyi University (YJ 201908, YJ201912).

\section{References}

1. ELMASSRY M.M., CHUNG E., JAY J.C., ABDUL N.H., SHEN C.L. Osteoprotective effect of green tea polyphenols and annatto-extracted tocotrienol in obese mice is associated with enhanced microbiome vitamin K2 biosynthetic pathways. The Journal of nutritional biochemistry, 86, 108492, 2020.

2. ELISA V.A., BECERRA H., LINA V. FMRP y las neuroliginas: la influencia de la actividad sensorial en las dinámicas del neurodesarrollo FMRP and Neuroligins: The Influence of Sensory Activity on Neurodevelopment Dynamics. Universitas Medica, 61 (4), 35, 2020.

3. TUNG W.C., RIZZO B., DABBAGH Y., SARASWAT S., ROMANCZYK M., EDELSYS C.H., ROCIA R.R., PAUL A.K., NJARA R., OLIVER D., KAREN W., JOE V. Polyphenols bind to low density lipoprotein at biologically relevant concentrations that are protective for heart disease. Archives of Biochemistry and Biophysics, 694, 2020.

4. YE H.M., LI G.P., YUAN X.Y., ZHENG M.Z. Fractionation and Bioavailability of Trace Elements in Wuyi Rock Tea Garden Soil. Polish Journal of Environmental Studies, 27 (1), 421, 2018.

5. CHEN H.K., YANG J.F. Research progress in quality being of Wuyi rock tea in different areas. Journal of Food Safety \& Quality, 2016.

6. PRAMANIK P., SAFIQUE S., JAHAN A. Humic substrates extracted by recycling factory tea waste improved soil properties and tea productivity: an innovative approach. International Journal of Environmental Science \& Technology, 1, 2018.

7. CHIEN H.H., TOKUDA M., MINH D.V., KANG Y.M., IWASAKI K., TANAKA S. Soil physicochemical properties in a high-quality tea production area of Thai Nguyen province in northern region, Vietnam. Soil Science and Plant Nutrition, 65 (1),73, 2019.

8. CHEN Y.Q., WANG X.S., GUO C.J., HUANG J., YU Z., NI D.J. Effects of Soil Characters on the Tea Quality in the Tea Region of Qin-Ba Mountain, Hubei Province, PR China. Tea, 39 (4), 212, 2013.

9. LIU J., WU L. C., CHEN D., YU Z.G., WEI C.J. Development of a soil quality index for Camellia oleifera forestland yield under three different parent materials in
Southern China. Soil and Tillage Research, 176, 45, 2018.

10. LIN Z.H., QI Y.P., CHEN R.B., ZHANG F.Z., CHEN L.S. Effects of phosphorus supply on the quality of green tea. Food Chemistry, 130 (4), 908, 2012.

11. MCLAREN T.I., SMERNIK R.J., MCLAUGHLIN M.J., MCBEATH T.M., KIRBY J.K., SIMPSON R.J., GUPPY C.N., DOOLETTE A.L., RICHARDSON A.E. Complex Forms of Soil Organic Phosphorus - A Major Component of Soil Phosphorus. Environmental Science \& Technology, 49 (22), 13238, 2015.

12. DOIG L.E., NORTH R.L., HUDSON J.J., HEWLETT C., LINDENSCHMIDT K.E., LIBER K. Phosphorus release from sediments in a river-valley reservoir in the northern Great Plains of North America. Hydrobiologia, 787 (1), 323, 2016.

13. LU H., HUANG S., STANLEY C.D., OSBORNE T.Z. Phosphorus Fractionation in Core Sediments from Haihe River Mainstream, China. Journal of Soil Contamination, 20 (1), 30, 2011.

14. IGNATOWICZ K. The impact of sewage sludge treatment on the content of selected heavy metals and their fractions. Environmental Research, 156, 19, 2017.

15. ALEMU B., MELESE A. Phosphorous Adsorption and Its Requirements by Bread Wheat Varieties (Triticum aestivum L.), In Acidic Soils of Cheha and Dinsho Districts, Southern Highlands of Ethiopia. Communication in Soil Science and Plant Analysis, 51 (2), 186, 2019.

16. YE H., YAN X., ZHOU R., WAN J., XU J. Distribution and Environmental Significance of Phosphorus Forms in Riparian Soils and River Sediments of Jianxi Basin, Fujian Province. Polish Journal of Environmental Studies, 26 (5), 2331, 2017.

17. Tea - Determination of water extract. ISO 9768:1990.

18. Determination of substances characteristic of green and black tea - Part 1: Content of total polyphenols in tea Colorimetric method using Folin-Ciocalteu reagent. ISO 14502-1:2005.

19. Determination of caffeine content (Reference method). ISO 4052:1983.

20. YAHYA R.T., HARRY L.P. A predictive-kinetic method for the quantitation of amino acids with ninhydrin. Analytica Chimica Acta, 173, 23, 1985.

21. ACKSEL A., BAUMANN K., HU Y.F., LEINWEBER P. A critical review and evaluation of some P-research methods, 50 (22), 2804, 2019.

22. WU B., CUI Y.H., WU X.H., JIA H.W., LI M. Discrimination of Tea Varieties by Using Infrared Spectroscopy with a Novel Generalized Noise Clustering. Spectroscopy and Spectral Analysis, 36 (7), 2094, 2016.

23. WANG Y.J., LI T.H., LI L.Q., NING J.M., ZHANG Z.Z. Micro-NIR spectrometer for quality assessment of tea: Comparison of local and global models. Spectrochemica Acta Part A-Molecular and Biomolecular Spectroscopy, 237, 2020.

24. SINGH G., KUMARI B., SINAM G., KUMAR N., MALLICK S. Fluoride distribution and contamination in the water, soil and plants continuum and its remedial technologies, an Indian perspective- a review. Environmental Pollution, 239, 95, 2018.

25. WANG X.L. Phosphorus Fractionation and Bio-availability in Surface Sediments from the Middle and Lower Reaches of the Yellow River. Procedia Environmental Sciences, 12 (2), 379, 2012.

26. ZHANG R.Y., WANG L.Y., WU F.C., SONG B.A. Phosphorus speciation in the sediment profile of 
Lake Erhai, southwestern China: Fractionation and 31 pNMR. Journal of environmental sciences, 25 (6), 1124, 2013.

27. DAI Z.M., ZHANG X.J., TANG C., MUHAMMAD N., WU J.J., BROOKES P.C., XU J.M. Potential role of biochar in decreasing soil acidification - A critical review. Science of the Total Environment, 581, 2017.

28. JAYASINGHE S.L., KUMAR L. Modeling the climate suitability of tea (Camellia sinensis (L.) O. Kuntze) in Sri Lanka in response to current and future climate change scenarios, 272, 102, 2019.

29. YU L.F., WANG S.Q., LI T.X., HAN L. Response of soil faunal communities to tea tree cultivars in the hilly region of western Sichuan, China. Scientia Horticulture, 275, 109701, 2021.

30. ANDA M., DAHLGREN R.A. Long-term response of tropical Andisol properties to conversion from rainforest to agriculture, Catena, 194, 104679, 2020.

31. WANG J.J., MUHAMMAD Z., HE P.H., SUN H., CHEN Q.S., LI H.H., OUYANG Q., GUO Z.M., ZHANG Z.Z., XU
D.L. Evaluating matcha tea quality index using portable NIR spectroscopy coupled chemometric algorithms. Journal of the Science of Food and Agriculture, 11 (1), 5019, 2019.

32. NAGHMA K., HASAN M. Tea polyphenols in promotion of human health. Nutrients, 11 (1), 2019.

33. FU X.B., ZHANG Y.L., QIU Y.L, SONG X.M. Protein 2 from Tea Geometrid, Ectropis obliqua. Journal of Agricultural and Food Chemistry, 66 (50), 13084, 2018.

34. YAN M.J., LIN Q., WU Y.Q., ZHANG H., CAI S.X., CHEN Z.C. Effects of different nitrogen fertilization treatments on soil condition of tea garden and tea quality. Ecology and Environmental Sciences, 23 (3), 452, 2014.

35. REN G.X., WANG Y.J., NING J.M., ZHANG Z.Z. Using near-infrared hyperspectral imaging with multiple decision tree methods to delineate black tea quality. Spectrochimica Acta Part A-Molecular and Biomolecular Spectroscopy, 237, 118407, 2020. 
